\title{
SISTEM INFORMASI PENGELOLAAN DATA SISWA PADA SMA NEGERI 02 BILAH HULU BERBASIS WEB
}

\author{
Deci Irmayani ${ }^{1)}$, Musthafa Haris Munandar ${ }^{2)}$ \\ Fakultas Sains dan Teknologi, Universitas Labuhanbatu \\ deacyirmayani@gmail.com ${ }^{1)}$, harismunandaaar@gmail.com ${ }^{2)}$
}

\begin{abstract}
ABSTRAK
Sistem Informasi Data Siswa sangatlah penting bagi sebuah organisasi sekolah dan pihak-pihak lain yang membutuhkan data siswa tersebut, dengan adanya informasi data siswa, kita bisa mengetahui tentang suatu info data siswa dengan efektif dan efesien. Adapun Bahasa Pemograman yang di gunakan dalam pembuatan aplikasi yang dimaksud adalah berbasis Web. Pembuatan databasenya menggunakan MySQL dan AppServ. Perancangan sistem dilakukan dengan metode waterfall yang merupakan model pengembangan sistem informasi yang sistematik dan sekuensial. Metode penggalian data yang digunakan adalah wawancara, observasi, dan studi kepustakaan. Hasil dari pembuatan program yakni ditujukan dengan Terselesaikan nya Aplikasi Sistem informasi Pengelolaan Data Siswa Berbasis Web. Semoga dengan adanya aplikasi ini, dapat meningkatkan Kinerja dalam proses informasi pengolaan data siswa dan pencarian data siswa yang dibutuhkan kapan saja di SMA NEGERI 02 BILAH HULU.
\end{abstract}

Kata Kunci: Berbasis Web, Waterfall, Mysql, AppServ

\section{PENDAHULUAN}

Perkembangan teknologi informasi yang semakin pesat sekarang ini menuntut kita untuk mengikuti arus perkembangan teknologi tersebut, begitu juga bagi instansi yang akan melakukan pemanfaatan teknologi komputer di bidang administrasi salah satunya adalah sistem informasi berbasis web. Bertujuan agar setiap pekerjaan dapat dilakukan dengan mudah dan cepat dengan hasil yang maksimal dalam hal memasukkan data (input), menyimpan data dan menampilkannya data (output). Sistem informasi pengelolaan data siswa berbasis web ini dirasa sangat diperlukan guna memberikan kemudahan kepada pihak sekolah khusus nya SMA Negeri 02 Bilah Hulu. Karena dengan adanya komputer akan memudahkan dalam mengelola segala administrasi, baik itu yang berhubungan dengan instansi, guru, maupun siswa.

\section{LANDASAN TEORI}

\subsection{Definisi Sistem}

Sistem adalah kumpulan dari sub-sub sistem yang saling berinteraksi antara sub sistem yang satu dengan sub sistem yang lain dalam mencapai tujuan yang sama. Dewasa ini ada dua pendekatan yang digunakan dalam mengartikan sistem yaitu kelompok yang lebih menekankan pada prosedurnya dan kelompok yang menekankan pada komponen-komponen atau elemennya.

Sistem didefinisikan sebagai sekumpulan prosedur yang saling berkaitan dan saling terhubung untuk melakukan suatu tugas bersama-sama. Secara garis besar, sebuah 
sistem informasi terdiri atas tiga komponen utama. Ketiga komponen tersebut mencakup software, hadrware dan brainware. Ketiga komponen ini saling berkaitan satu sama lain Beroperasinya suatu sistem adalah dengan maksud dan tujuan tertentu, maksud dan tujuan akhir yang diinginkan akan bisa tercapai hanya bila dilakukan suatu kegiatan terkontrol.

\subsection{Pengertian Informasi}

Informasi merupakan hasil pengolahan dari sebuah model, formasi, organisasi, ataupun suatu perubahan bentuk dari data yang memiliki nilai arti, dan bisa digunakan untuk menambah manfaat ataupun pengetahuan bagi penerimanya (Pratama, 2014). Informasi adalah data yang telah diklasifikasikan atau diolah atau interpretasikan untuk digunakan dalam proses pengambilan keputusan (Sutabri, 2013). Dapat disimpulkan bahwa informasi adalah data yang sudah diolah atau dimanipulasikan sesuai dengan keperluan tertentu yang memiliki nilai dan manfaat.

\subsection{Pengertian Database}

Database merupakan kumpulan file - file yang saling berkaitan dan berinteraksi, relasi tersebut bila ditunjukan dengan kunci dari tiap tiap file yang ada. Satu database menunjukkan suatu kumpulan data yang dipakai dalam suatu lingkup perusahaan, instansi. Pengolahan database merupakan suatu cara yang dilakukan terhadap file-file yang berada di suatu instansi yang mana file tersebut dapat disusun, diurut, diambil sewaktu-waktu serta dapat ditampilkan dalam bentuk suatu laporan sehingga dapat mengolah file-file yang berisikan informasi tersebut secara rapi.

Komponen-komponen DBMS : a. Interface, yang didalamnya terdapat bahasa manipulasi data (data manipulation language).

b. Bahasa definisi data (datadefinition language) untuk skema eksternal, skema konsepsual dan skema internal.

c. Sistem kontrol basis data(Database Control System) yang mengakses basis data karena adanya perintah dari bahasa manipulasi data.

Contoh bahasa menggunakan komponenkomponen tersebut adalah SQL (Structured Query Language). SQL merupakan bahasa standar yang digunakan oleh kebanyakan aplikasi- aplikasi DBMS.

\subsection{Pengertian MySQL}

MySQL dikembangkan oleh pengembang dan konsultan database bernama MySQL AB sekitar tahun 1994 di Swedia. Tujuan awal dikembangkan untuk mengembangkan aplikasi berbasis web pada client. MySQL sebuah perangkat lunak sistem manajemen basis data SQL (database management system) atau DBMS yang multithread, multi-user, dengan sekitar 6 juta instalasi di seluruh dunia. MySQL merupakan perangkat lunak (software) gratis dibawah lisensi GPL (GNU General Public License). MySQL sebagai sebuah implementasi dari sistem manajemen basis data relasional (RDBMS-Relational DataBase Management System) didistribusikan secara gratis dibawah lisensi GPL (General Public License). Dapat secara bebas menggunakan MySQL, namun dengan batasan tidak boleh dijadikan produk turunan yang bersifat komersial. MySQL merupakan turunan konsep utama dalam basis data, yaitu SQL. SQL adalah sebuah konsep pengoperasian basis data, terutama untuk pemilihan atau seleksi dan input data, yang 
memungkinkan pengoperasian data dikerjakan dengan mudah.

\subsection{Pengertian Web}

World wide web atau sering di kenal sebagai web adalah suatu layanan sajian informasi yang menggunakan konsep hyperlink (tautan), yang memudahakan surfer (sebutan para pemakai komputer yang melakukan browsing atau penelusuran informasi melalui internet). Keistimewaan inilah yang telah menjadikan web sebagai service yang paling cepat pertubuhannya. Web mengijinkan pemberian highlight (penyorotan atau penggaris bawahan) pada kata-kata atau gambar dalam sebuah dokumen untuk menghubungkan atau menunjuk ke media lain seperti dokumen, frase, movie clip, atau file suara. Web dapat menghubungkan dari sembarang tempat dalam sebuah dokumen atau gambar ke sembarang tempat di dokumen lain. Dengan sebuah browser yang memiliki Grapihcal User Interface (GUI), link-link dapat di hubungkan ke tujuannya dengan menunjuk link tersebut dengan mouse dan menekannya. Penemu Situs Web. Penemu situs Web adalah Sir Timothy Jhon BermersLee, sedangakan situs web yang tersambung dengan jaringan pertama kali muncul pada tahun 1991. Maksud dari timothy ketika merancang situs web adalah untuk memudahkan tukar menukar dan memperbaharui informasi pada sesama peneliti di tempat ia bekerja. Pada tanggal 30 april 1993, CERN (tempat dimana timothy bekerja) mengumumkan bahwa www dapat digunakan secara garatis oleh public.

\subsection{Konsep Sistem Informasi}

Definisi Sistem Informasi menurut Azhar Susanto (2008) adalah sebagai berikut : "Sistem informasi adalah kumpulan dari subsistem apapun baik phisik ataupun non phisik yang saling berhubungan satu sama lain dan bekerja sama secara harmonis untuk mencapai satu tujuan yaitu mengolah data menjadi informasi yang berarti dan berguna".

Menurut Robert yang dikutip oleh Minarni dan Saputra (2011), Sistem informasi adalah suatu sistem di dalam suatu organisasi yang mempertemukan kebutuhan pengolahan transaksi harian, mendukung operasi, bersifat manajerial dan kegiatan strategi dari suatu organisasi dan menyediakan pihak luar tertentu dengan laporan - laporan yang diperlukan.

\subsection{Pengertian Xampp}

Menurut MADCOMS (2016) "Xampp adalah sebuah paket kumpulan software yang terdiri dari Apache, MySQL, PhpMyAdmin, PHP, Perl, Filezilla, dan lain.” Xampp berfungsi untuk memudahkan instalasi lingkungan PHP, di mana biasanya lingkungan pengembangan web memerlukan PHP, Apache, MySQL dan PhpMyAdmin.

XAMPP adalah perangkat lunak bebas, yang mendukung banyak sistem operasi, merupakan kompilasi dari beberapa program. Fungsinya adalah sebagai server yang berdiri sendiri (localhost), yang terdiri atas program Apache HTTP Server, MySQL database, dan penerjemah bahasa yang ditulis dengan bahasa pemrograman PHP dan Perl. Nama XAMPP merupakan singkatan dari $\mathrm{X}$ (empat sistem operasi apapun), Apache, MySQL, PHP dan Perl. Program ini tersedia dalam GNU General Public License dan bebas, merupakan web server yang mudah digunakan yang dapat melayani tampilan halaman web yang dinamis.

\section{METODE PENELITIAN}

Metode penelitian yang digunakan dalam penyusunan Tugas Akhir ini adalah dengan menggunakan metode waterfall atau disebut juga dengan metode air terjun. Model ini 
berkembang secara sistematis dari satu tahap ke tahap lain dalam model seperti air terjun. Metode pengumpulan data merupakan tejnik atau cara yang dilakukan untuk mengumpulkan data.

\subsection{Metode Pengumpulan Data}

Dalam penelitian ini penulis memperoleh data dengan metode sebagai berikut:

1. Observasi (Pengamatan)

Metode observasi adalah metode pengumpulan data dengan cara mengamati secara langsung data, proses dan objek permasalahan untuk memperoleh data-data, observasi dilakukan di SMAN 02 BILAH HULU.

2. Wawancara (Interview)

Wawancara (Interview) adalah metode pengumpulan data yang dilakukan penulis dengan cara tanya jawab kepada pihak yang bersangkutan yaitu Bapak Muda Ritonga, S.Pd, MM selaku Kepala Sekolah di SMAN 02 BILAH HULU, agar informasi yang didapat dapat membantu dalam perancangan Sistem Informasi Pengelolaan Data Siswa yang akan dibuat.

\section{Studi Pustaka}

Metode Kepustakaan adalah metode pengumpulan data yang didapat dari beberapa jurnal yang berisi teori-teori yang berkaitan dengan masalah yang akan dibahas. Pada metode ini, peneliti mendapat banyak masukan tentang bagaimana merancang suatu sistem.

\section{Dokumentasi}

Proses dokumentasi yaitu proses pengambilan data yang dilakukan dengan melihat data, catatan, dan dokumen yang terkait dengan sistem pengelolaan data siswa yang terdapat di SMAN 02 BILAH HULU.

\subsection{Metode Perancangan SDLC (System Deveploment Life Cycle)}

SDLC (Systems Development Life Cycle, Siklus Hidup Pengembangan Sistem) atau Systems Life Cycle (Siklus Hidup Sistem), dalam rekayasa sistem dan rekayasa perangkat lunak, adalah proses pembuatan dan pengubahan sistem serta model dan metodologi yang digunakan untuk mengembangkan sistemsistem tersebut. Konsep ini umumnya merujuk pada system komputer atau informasi. SDLC juga merupakan pola yang diambil untuk mengembangkan sistem perangkat lunak, yang terdiri dari tahap-tahap: rencana, analisis, desain, implementasi, ujicobadan pengelolaan. Dalam rekayasa perangkat lunak konsep SDLC mendasari berbagai jenis metodologi pengembangan perangkat lunak. Metodologimetodologi ini membentuk suatu kerangka kerja untuk perencanaan dan pengendalian pembuatan sistem informasi.

\subsection{DFD(Data Flow Diagram)}

Adapun DFD Level 0 dari sistem informasi Pengelolaan Data Siswa :

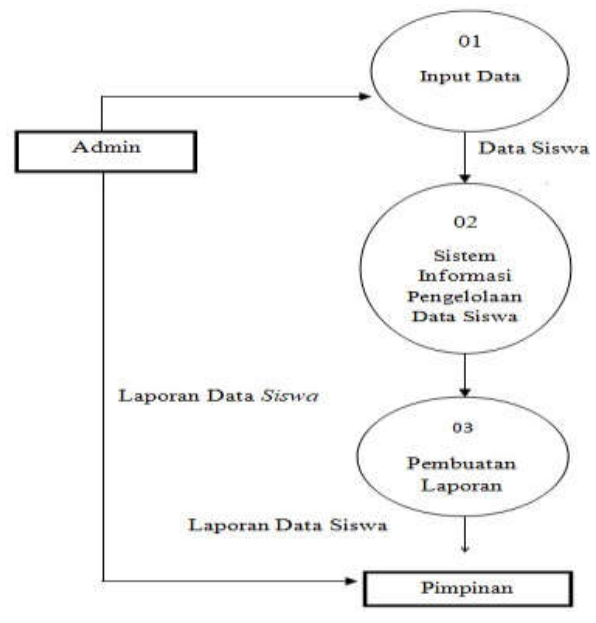

Gambar 3.3 DFD Pengelolaan Data Siswa

Penjelasan :

Pada gambar 3.1 admin memasukan username dan password dan login ke sistem. Kemudian admin menginputkan data 
siswa ke sistem dan sistem

membuat/mencetak laporan siswa.

\subsection{Rancangan Interface}

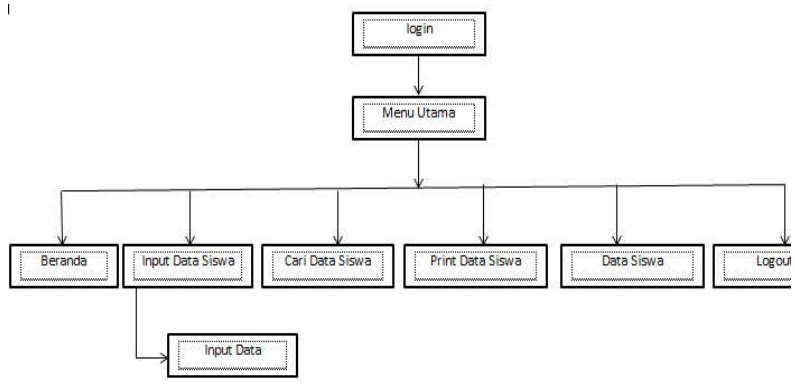

Gambar 3.4 Rancangan Interface

Penjelasan:

Pada gambar 3.4 merupakan rancangan interface dari ssitem informasi pengelolaan data siswa, di tampilannya ada menu utama, meliputi Beranda, Input Data Siswa, Cari Data Siswa, Print Data Siswa, Data Siswa dan Logout. Di menu Input data siswa ada bagian input data.

\section{HASIL DAN PEMBAHASAN}

\subsection{Hasil Dan Pembahasan}

Sistem yang diusulkan ini bukanlah sekedar untuk mempercepat atau mengoptimalkan suatu kegiatan operasional, dalam penghematan waktu dan biaya. Diharapkan dengan adanya sistem informasi pengelolaan data siswa ini dapat memperoleh informasi yang dibutuhkan setiap saat untuk melakukan pengambilan keputusan secara cepat dan tepat.

Hasil dan pembahasan dari sistem informasi pengelolaan data siswa dapat digolongkan menjadi beberapa bagian yaitu bagian menu utama, bagian input sistem dan bagian output sistem.

\subsubsection{Tampilan Menu Bar}

\section{Menu Utama}

Tampilan Menu ini menunjukan beberapa menu yang ada di dalam program/ sistem. Berupa menu beranda, input data siswa, cari data siswa, print data siswa, data siswa dan logout. Adapun penjelasannya adalah sebagai berikut:

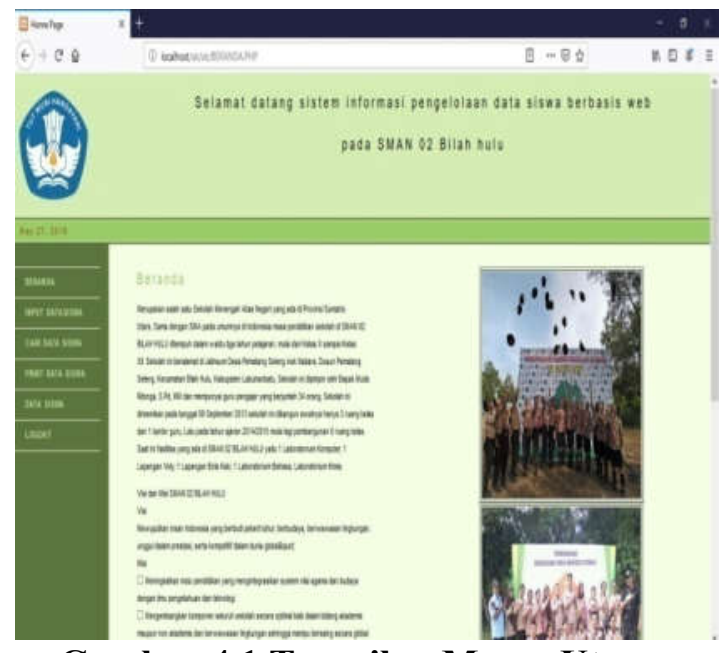

Gambar 4.1 Tampilan Menu Utama

\section{Menu Input}

\section{a. Input Data Siswa}

Form input data siswa digunakan untuk melakukan pengelolaan data siswa. Data tersebut dapat dilihat di menu print data siswa atau data siswa lalu masukkan nis, nama,tempat tanggal lahir, Jenis kelamin, agama, alamat, kelas, wali kelas, jurusan, tahun angkatan, status dan tambahkan foto siswa lalu klik simpan data siswa form tersebut diisi sesuai data siswa yang ada. misalnya user mengisi nis 01 ,

nama eka wahyu albara, tempat tanggal lahir pemsel 2401 1997, Jenis kelamin laki-laki, agama islam, alamat pemsel, kelas 12 ips 1, wali kelas devi andriani, jurusan ipa, tahun angkatan 2015 status Alumni maka akan muncul data berupa data siswa adapun form 
input data siswa dapat dilihat pada gambar berikut.

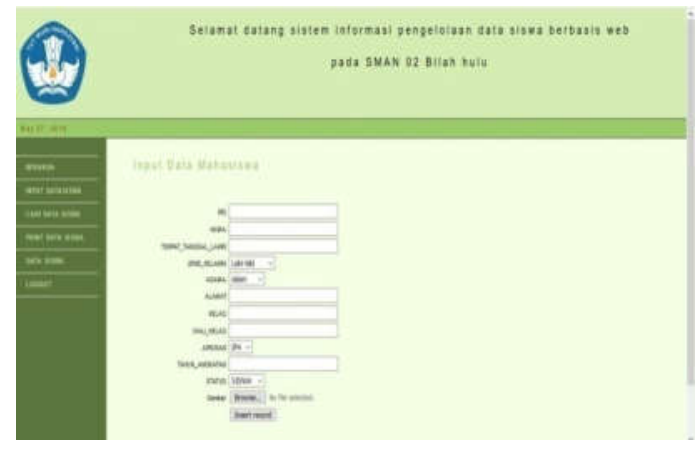

\section{Gambar 4.2 Tampilan Input data siswa}

\section{Menu Keluaran (Output)}

1. Laporan Data Siswa

Laporan data siswa merupakan output yang dihasilkan dari sistem informasi pengelolaan data siswa yang sudah dilakukan penginputan datanya, output akan ditampilkan kelayar, maupun dicetak menggunkan printer, maka secara otomatis dikirim ke print pencetak dan print cetak akan bekerja mencetak laporan. Adapun form input data siswa yang ada di dalam informasi data siswa dapat dilihat pada gambar berikut:

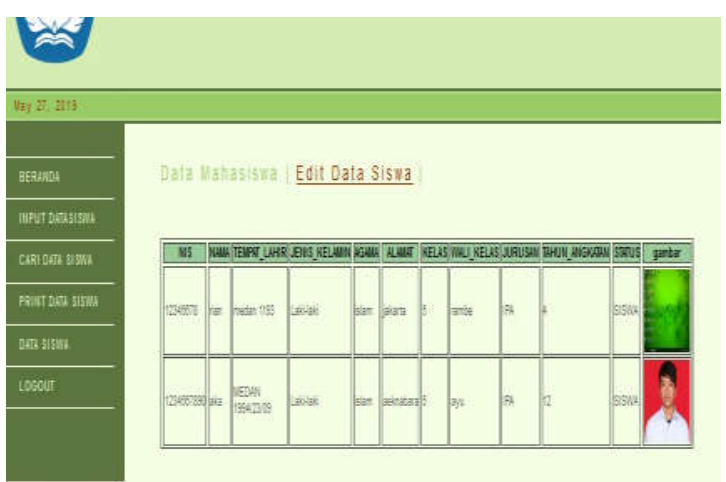

Gambar 4.3 Laporan data siswa
Dalam penerapan sistem yang dibuat tidak terlepas dari perangkat keras dan perangkat lunak. Untuk menguji aplikasi atau sistem informasi pengelolaan data siswaberbasis web pada SMAN 02 BILAH HULU, digunakan komputer dengan spesifikasi yang diuraikan dalam beberapa spesifikasi yang diuraikan dalam beberapa bagian yaitu sebagai berikut:

\section{KESIMPULAN DAN SARAN}

\subsection{Kesimpulan}

Kesimpulan yang dapat diambil dari pembuatan Tugas Akhir ini adalah :

1. Dengan adanya sistem komputerisasi pengelolaan data siswa maka pekerjaan proses pengolahan data siswa dapat dilakukan dengan cepat dan akurat, mudah dan lebih baik.

2. Sistem Informasi pengolahan data siswa yang baik akan memudahkan dalam pengambilan data siswa sehingga dapat meningkatkan kinerja.

3. Pembuatan program dengan menggunakan PHP dan MySQL lebih mudah dimengerti oleh user karena menggunakan bahasa pemrograman berbasis web yang mudah dipahami.

\subsection{Saran}

Dalam hal ini, penulis memberikan saran yang kiranya dapat bermanfaat untuk kemajuan sistem informasi pengelolaan data siswa di SMAN 02 Bilah Hulu, yaitu:

1. Diharapkan adanya pengembangan lebih lanjut dari sistem informasi khususnya pengelolaan data siswa.

2. Lebih lanjut untuk disarankan untuk terus diteliti dan dikembangkan lagi baik oleh peneliti maupun dari pihak terkait. Menu-menu yang terdapat dalam program masih terlalu sederhana, untuk

\section{Pembahasan}


itu diperlukan pengembangan sistem yang lebih sempurna

3. Melakukan pemeliharaan dan perawatan sistem yang diusulkan ini.

\section{DAFTAR PUSTAKA}

[1] A. RINI, "SISTEM INFORMASI PENGOLAHAN DATA PENANGGULANGAN BENCANA PADA KANTOR BADAN PENANGGULANGAN BENCANA DAERAH (BPBD) KABUPATEN PADANG PARIAMAN," IOSR J. Econ. Financ., vol. 3, no. 1, p. 56, 2016.

[2] A. Halim and S. Hasan, "SISTEM INFORMASI PENGELOLAAN UANG KOMITE MENGGUNAKAN BORLAND DELPHI 7 PADA SMA NEGERI 5 KOTA TERNATE," Sist. Inf. Pengelolaan Uang Kom. Menggunakan Borl. Delphi 7 Pada Sma Negeri 5 Kota Ternate Data, vol. 2, no. April 2017, pp. 28-34, 2017.

[3] D. Lavarino and Y. Wiyli, "RANCANG BANGUN E - VOTING BERBASIS WEBSITE DI UNIVERSITAS NEGERI SURABAYA," IOSR J. Econ. Financ., vol. 6, no. 1, p. 56, 2016.

[4] Emil salim Podungge and Asmawati, "Sistem Informasi Data Nilai Siswa Pada SMP Negeri 2 Bahodopi di Kabupaten Morowali," J. Elektron. Sist. Inf. dan Komput., vol. 3, no. 1, pp. 1-128, 2017.

[5] F. Ayu and N. Permatasari, "Perancangan Sistem Informasi Pengolahan Data Praktek Kerja Lapangan (PKL) Pada Devisi Humas Pt. Pegadaian," vol. 2, no. 2, pp. 12-26, 2018.

[6] F. Kamran and N. faisall Kharie, "Sistem Informasi Akademik Berbasis Web Pada Politeknik Sains Dan Teknologi Wiratama Maluku Utara," Indones. J. Inf. Syst. Sist., vol. 1, no. September 2016, pp. 39-46, 2016.

[7] K. Arif and A. Ambarita, "SISTEM PENGOLAHAN DATA REKAM MEDIS BERBASIS WEB PADA PUSKESMAS PERAWATAN JAMBULA KOTA TERNATE DATA," vol. 1, no. September 2016, pp. 68-77, 2016.

[8] M. Tabrani and E. Pudjiarti, "Penerapan Metode Waterfall Pada Sistem Informasi Inventori Pt. Pangan Sehat Sejahtera," J. Inkofar, vol. 1, no. 2, pp. 30-40, 2017.
[9] M. Faizal and putri listya Sanda, "Jurnal Teknologi Informasi dan Komunikasi STMIK Subang, Oktober 2017 ISSN: 2252-4517," Sist. Inf. Pengolah. DATA PEGAWAI Berbas. WEB (STUDI KASUS DI PT Perkeb. Nusant. VIII TAMBAKSARI, pp. 1-23, 2017.

[10] N. A. Rahmawati and A. C. Bachtiar, "Analisis dan perancangan sistem informasi perpustakaan sekolah berdasarkan kebutuhan sistem," Berk. Ilmu Perpust. dan Inf., vol. 14, no. 1, p. 76, 2018.

[11] Ponidi and S. Fitrajaya, "Perancangan Sistem Informasi Pendataan Penduduk Berbasis Web Menggunakan Metode Waterfall Pada Kecamatan Gadingrejo," J. TAM (Technology Accept. Model., vol. 4, pp. 68-74, 2015.

[12] R. V Palit, Y. D. Y. Rindengan, and A. S. M. Lumenta, "Rancangan Sistem Informasi Keuangan Berbasis Web Di Jemaat GMIM Bukit Moria Malalayang," E-Journal Tek. Elektro dan Komput. vol, vol. 4, no. 7, pp. 1-7, 2015.

[13] S. Ali and A. Ambarita, "SISTEM INFORMASI DATA BARANG INVENTARIS BERBASIS WEB PADA KEJAKSAAN NEGERI TERNATE," Indones. J. Inf. Syst. Sist., vol. 1, no. April 2016, pp. 31-38, 2016.

[14] S. R. S. Siregar and P. Sundari, "Rancangan Sistem Informasi Pengelolaan Data Kependudukan Desa ( Studi Kasus di Kantor Desa Sangiang Kecamatan Sepatan Timur )," Sisfotek Glob., vol. 6, no. 1, pp. 76-82, 2016.

[15] T. Desyani, "Perancangan Sisitem Informasi Pengelolaan Data Obat pada Apotek Sinar Mulia Berbasis Web," vol. 3, no. 1, pp. 51-60, 2018.

[16] Yusri, "Sistem Informasi Perpustakaan Berbasis Web Pada SMP Frater Makassar," J. Sist. Inf. Bisnis, vol. XIV, no. 2, pp. 66-77, 2015.

[17] M. Nasution, S. Pohan, and S. Z. Harahap, "Implementasi Obrim (Option-Based Risk Management) Sebagai Framework Investasi Teknologi Informasi Perguruan Tinggi (Studi Kasus: Amik Labuhan Batu)," JURNAL INFORMATIKA, vol. 8, no. 1, pp. 26-35, Jan. 2020. 